\title{
Numerical Taxonomy of Species in the Genus Mallomonas (Chrysophyta) from China
}

\author{
Jia Feng and Shulian Xie \\ College of Life Science, Shanxi University, Taiyuan 030006, China \\ Correspondence should be addressed to Shulian Xie; xiesl@sxu.edu.cn
}

Received 4 June 2013; Accepted 26 June 2013

Academic Editors: I. Bisht and P. De los Ríos Escalante

Copyright (C) 2013 J. Feng and S. Xie. This is an open access article distributed under the Creative Commons Attribution License, which permits unrestricted use, distribution, and reproduction in any medium, provided the original work is properly cited.

\begin{abstract}
Mallomonas is one of the biggest genera of Chrysophyta. In total, 37 species and 2 varieties have been recorded in China. Because of their narrow ecological optimum, species of this genus are considered as valuable bioindicators. However, taxonomy of Mallomonas remains unclear. We studied the numerical taxonomy of all the species and varieties recorded in China using Ward's method and the furthest neighbor method based on 52 morphological characters. Shown in the phylogenetic trees, those species could be divided into two major clusters. One cluster includes 5 small clusters and another includes 2 . The results of numerical taxonomy are partially consistent with the traditional ones with some divergences. Furthermore, the diversity of silicified scales including shapes and structures was confirmed as the most important character for identification of Mallomonas species.
\end{abstract}

\section{Introduction}

The genus Mallomonas, which was created by Perty in 1852, is reported as one of the biggest genera in Chrysophyta $[1,2]$. It is comprised of 163 species around the world so far, of which 37 species and 2 varieties are from China [314]. Mallomonas are unicellular, free-swimming, freshwater organisms. Because of their narrow ecological optimum, Mallomonas species are considered as valuable bioindicators to both recent and historical environments, as well as for biomonitoring [15-18]. Smol suggested that morphological variability of silica structures within individual species could represent an important piece of information for biomonitoring studies [19]. Therefore, it is important for us to make a clear and reasonable classification system of this genus.

The basic taxonomic system of the genus Mallomonas was first established in 1933 and has been modified for several times [20-27]. Nowadays, the genus Mallomonas is traditionally divided into sections and series in mainly the morphology of scales, which is considered as the most important taxonomic character for species identification and the taxonomy of the species $[5,28]$. However, we shall be aware that this classification based mainly on resemblances and the difference in the structures of scales and bristles may be highly artificial, because it is still unknown which scale characters are stable enough to be selected as reliable taxonomical markers. Also, since it is hard to collect enough samples of unicellular bodies for molecular analysis, phylogenetic studies that used the molecular data were also difficult for generic taxonomy and phylogeny of the genus Mallomonas. Therefore, the phylogenetic reliability of individual morphological characteristics remains unclear.

Numerical taxonomy was developed in the late 1950s and had been broadly successful in taxonomy of microalgae, mainly in identification of the subspecies. In numerical taxonomy, several characters are selected equally and used to evaluate the similarity of organisms calculated using mathematical methods. And such similarity could be used to differentiate species and cluster certain species to new groups. As numerical taxonomy simultaneously deals with many characters, it could avoid the limitation of the information of the holotype and subjective factors during identification. And the analyses results could give us one or several characters, which should be selected as the main characters for species identification and taxonomy. In this work, we have carried out the multicharacter analysis of the 39 Mallomonas species recorded in China using the numerical taxonomy. Our work provides a comparatively objective description of the system evolution and the taxonomy research on Mallomonas. 
TABLE 1: The species of Mallomonas in China.

\begin{tabular}{|c|c|c|}
\hline No. & Species & Reference \\
\hline 1 & M. acaroides Perty em. Iwanoff & $\begin{array}{l}\text { Kristiansen, 1989, 1990, } 2002 \text { [7, 10, 28]; Kristiansen and Tong, } 1989 \text { [9]; Wei } \\
\text { and Kristiansen, 1994, } 1998 \text { [12, 13]; Wei and Yuan, } 2001 \text { [14] }\end{array}$ \\
\hline 2 & M. akrokomos Ruttner & $\begin{array}{l}\text { Kristiansen, 1989, 1990, } 2002 \text { [7, 10, 28]; Kristiansen and Tong, } 1989 \text { [9]; Wei } \\
\text { and Kristiansen, } 1994 \text { [12]; Wei and Yuan, } 2001 \text { [14] }\end{array}$ \\
\hline 3 & M. alata Asmund et al. & Kristiansen, 1989, $2002[9,28]$ \\
\hline 4 & $\begin{array}{l}\text { M. alpina Pascher et Ruttner em. Asmund et } \\
\text { Kristiansen }\end{array}$ & $\begin{array}{l}\text { Kristiansen, 1989, 1990, } 2002 \text { [7, 10, 28]; Kristiansen and Tong, } 1989 \text { [9]; Wei } \\
\text { and Kristiansen, 1994, } 1998 \text { [12, 13]; Wei and Yuan, } 2001 \text { [14] }\end{array}$ \\
\hline 5 & M. annulata (Bradley) Harris & $\begin{array}{l}\text { Kristiansen, 1989, } 2002 \text { [7, 28]; Kristiansen and Tong, } 1989 \text { [9]; Wei and } \\
\text { Kristiansen, 1994, } 1998 \text { [12, 13]; Wei and Yuan, } 2001 \text { [14] }\end{array}$ \\
\hline 6 & M. areolata Nygaard & $\begin{array}{l}\text { Kristiansen, 1989, } 2002 \text { [7, 28]; Wei and Kristiansen, } 1994 \text { [12]; Wei and Yuan, } \\
2001[14]\end{array}$ \\
\hline 7 & M. allorgei (Deflandre) Conrad & Kristiansen, $2002[28]$ \\
\hline 8 & M. calceolus Bradley & Wei and Kristiansen, 1994 [12]; Kristiansen, 2002 [28] \\
\hline 9 & M. caudata Iwanoff em. Krieger & $\begin{array}{l}\text { Wei and Kristiansen, 1994, } 1998 \text { [12, 13]; Wei and Yuan, } 2001 \text { [14]; Kristiansen, } \\
2002 \text { [28] }\end{array}$ \\
\hline 10 & M. corymbosa Asmund et Hilliard & $\begin{array}{l}\text { Kristiansen, 1989, } 2002 \text { [7, 28]; Wei and Kristiansen, } 1994 \text { [12]; Wei and Yuan, } \\
2001 \text { [14] }\end{array}$ \\
\hline 11 & $\begin{array}{l}\text { M. costata Dürrschmidt em Asmund et } \\
\text { Kristiansen }\end{array}$ & Wei and Kristiansen, 1998 [13]; Wei and Yuan, 2001 [14]; Kristiansen, 2002 [28] \\
\hline 12 & M. crassisquama (Asmund) Fott & $\begin{array}{l}\text { Wei and Kristiansen, 1994, } 1998 \text { [12, 13]; Wei and Yuan, } 2001 \text { [14]; Kristiansen, } \\
2002[28]\end{array}$ \\
\hline 13 & M. cratis Harris et Bradley & Kristiansen, $1990[10]$ \\
\hline 14 & M. cyathellata Wujek et Asmund & $\begin{array}{l}\text { Wei and Kristiansen, 1994, } 1998 \text { [12, 13]; Wei and Yuan, } 2001 \text { [14]; Kristiansen, } \\
2002[28]\end{array}$ \\
\hline 15 & M. elongata Reverdin & $\begin{array}{l}\text { Kristiansen, 1989, } 2002 \text { [7, 28]; Kristiansen and Tong, } 1989 \text { [9]; Wei and } \\
\text { Kristiansen, 1994, } 1998 \text { [12, 13]; Wei and Yuan, } 2001 \text { [14] }\end{array}$ \\
\hline 16 & M. flora Harris et Bradley & Wei and Yuan, 2001 [14]; Kristiansen, 2002 [28] \\
\hline 17 & M. grata Takahashi & $\begin{array}{l}\text { Kristiansen, 1989, } 2002 \text { [7, 28]; Kristiansen and Tong, } 1989 \text { [9]; Wei and } \\
\text { Kristiansen, 1994, } 1998 \text { [12, 13]; Wei and Yuan, } 2001[14]\end{array}$ \\
\hline 18 & M. guttata Wujek & $\begin{array}{l}\text { Kristiansen and Tong, } 1989 \text { [9]; Wei and Kristiansen, } 1998 \text { [13]; Wei and Yuan, } \\
2001 \text { [14]; Kristiansen, } 2002 \text { [28] }\end{array}$ \\
\hline 19 & M. guttata var. simplex Nicholls & Wei and Yuan, $2001[14] ;$ Kristiansen, $2002[28]$ \\
\hline 20 & M. heterospina Lund & $\begin{array}{l}\text { Kristiansen, 1989, } 2002 \text { [7, 28]; Kristiansen and Tong, } 1989 \text { [9]; Wei and } \\
\text { Kristiansen, } 1994 \text { [12]; Wei and Yuan, } 2001 \text { [14] }\end{array}$ \\
\hline 21 & M. insignis Pénard & Kristiansen, 1989, $2002[7,28]$ \\
\hline 22 & M. mangofera Harris et Bradley & $\begin{array}{l}\text { Kristiansen, 1989, } 2002 \text { [7, 28]; Kristiansen and Tong, } 1989 \text { [9]; Wei and } \\
\text { Kristiansen, 1994, } 1998 \text { [12, 13]; Wei and Yuan, 2001 [14] }\end{array}$ \\
\hline 23 & M. eoa & Kristiansen and Tong, 1988, $1991[6,11] ;$ Kristiansen, $2002[28]$ \\
\hline 24 & M. splendens & Kristiansen and Tong, 1991 [11]; Kristiansen, 2002 [28] \\
\hline 25 & $\begin{array}{l}\text { M. matvienkoae (Matvienko) Asmund et } \\
\text { Kristiansen }\end{array}$ & $\begin{array}{l}\text { Kristiansen, 1989, } 2002 \text { [7, 28]; Kristiansen and Tong, } 1989 \text { [9]; Wei and } \\
\text { Kristiansen, 1994, } 1998 \text { [12, 13]; Wei and Yuan, } 2001[14]\end{array}$ \\
\hline 26 & M. multiunca Asmund & Wei and Yuan, 2001 [14]; Kristiansen, 2002 [28] \\
\hline 27 & M. multisetigera Dürrschmidt & Kristiansen, 1989, 2002 [7, 28]; Kristiansen and Tong, 1989 [9] \\
\hline 28 & M. oviformis Nygaard & $\begin{array}{l}\text { Kristiansen, 1989, } 2002 \text { [7, 28]; Wei and Kristiansen, } 1994 \text { [12]; Wei and Yuan, } \\
2001[14]\end{array}$ \\
\hline 29 & M. papillosa Harris et Bradley & $\begin{array}{l}\text { Kristiansen, 1989, } 2002 \text { [7, 28]; Wei and Kristiansen, } 1994 \text { [12]; Wei and Yuan, } \\
2001 \text { [14] }\end{array}$ \\
\hline 30 & M. parvula Dürrschmidt & Wei and Kristiansen, 1994 [12]; Wei and Yuan, 2001 [14]; Kristiansen, 2002 [28] \\
\hline 31 & M. peronoides (Harris) Momeu et Péterfi & $\begin{array}{l}\text { Kristiansen, 1989, } 2002 \text { [7, 28]; Wei and Kristiansen, 1994, } 1998 \text { [12, 13]; } \\
\text { Kristiansen and Tong, } 1989 \text { [9]; Wei and Yuan, } 2001[14]\end{array}$ \\
\hline
\end{tabular}


TABle 1: Continued.

\begin{tabular}{lcl}
\hline No. & \multicolumn{1}{c}{ Species } & Reference \\
\hline 32 & $\begin{array}{c}\text { M. peronoides var. bangladeshica Takahashi } \\
\text { et Hayakawa }\end{array}$ & Wei and Yuan, 2001 [14]; Kristiansen, 2002 [28] \\
\hline 33 & M. portae-ferreae Péterfi et Asmund & Wei and Kristiansen, 1994 [12], Wei and Yuan, 2001 [14]; Kristiansen, 2002 [28] \\
\hline 34 & M. pseudocratis Dürrschmidt & Wei and Yuan, 2001 [14]; Kristiansen, 2002 [28] \\
\hline 35 & M. punctifera Korshikov & $\begin{array}{l}\text { Kristiansen, 1989, 2002 [7, 28]; Kristiansen and Tong, 1989 [9]; Wei and } \\
\text { Kristiansen, 1994 [12]; Wei and Yuan, 2001 [14] }\end{array}$ \\
\hline 36 & M. rasilis Dürrschmidt & Wei and Kristiansen, 1998 [13]; Kristiansen, 2002 [28] \\
\hline 37 & M. striata Asmund & $\begin{array}{l}\text { Kristiansen, 1989, 1990, 2002 [7, 10, 28]; Kristiansen and Tong, 1989 [9]; Wei } \\
\text { and Kristiansen, 1994 [12] }\end{array}$ \\
\hline 38 & M. tolerans (Asmund \& Hillard) Asmund et & Kristiansen, 1990 [10] \\
\hline 39 & K. tonsurata Teiling & $\begin{array}{l}\text { Kristiansen, 1989, 1990, 2002 [7, 10, 28]; Wei and Kristiansen, 1994, 1998 } \\
{[12,13] ; \text { Wei and Yuan, 2001 [14] }}\end{array}$ \\
\hline
\end{tabular}

Furthermore, it has been showed that the shape of the rib and submarginal rib together should be selected as the most important characters, which would help us identify new species and deal with new records.

\section{Materials and Methods}

The species of Mallomonas recorded in China, which included 37 species and 2 varieties as taxonomic operated units, were selected for numerical taxonomy studies (Table 1). Fifty-two morphological characters had been selected and examined according to the following criteria (Table 2). First, all of them were stable and had been commonly used for taxonomic identification in this species. Second, the variability among different taxa could be observed in a preliminary review of herbarium material. Third, such characters should be denoted as dual dates.

Hierarchical cluster analysis is a general approach for cluster analysis, in which the objective is to group together objects or records closed to one another. In this work, hierarchical cluster analysis of all the samples was clustered using the furthest neighbor method and Ward's method as described by Lu [29]. These analyses were performed with the statistical software package "SPSS 12.0” [29].

\section{Results}

Identification of a species and taxonomy depends on the different shape, size, physiological characters, DNA characters, and living environment, and so forth, of the samples. These characters could be divided into two types, qualitative characters and quantitative characters, respectively. In our work, all the 52 dual characters selected belonged to qualitative characters since they were more directly visual and easier for examination. It could be found that most of these characters with remarkable variation selected according to the principle were shape and structure of the silicified scales, further confirming that the variations of the silicified scales were the most important characters for identification and taxonomic studies in Mallomonas, consistent with the related studies before.
TABLE 2: Characters and status used in the study.

\begin{tabular}{|c|c|}
\hline No. & Characters and status \\
\hline 1 & Scale small (1), no (0) \\
\hline 2 & Scale larger (1), no (0) \\
\hline 3 & Scale oval or elliptical (1), no (0) \\
\hline 4 & Scale round (1), no $(0)$ \\
\hline 5 & Scale symmetrical (1), no (0) \\
\hline 6 & Large pores on the scale observed with LM (1), absent (0) \\
\hline 7 & Body scale with subcircular peculiar appendix (1), absent (0) \\
\hline 8 & Dark twisting "vermiform" on the scale (1), absent (0) \\
\hline 9 & Scale with appendages "cyathi” (1), absent (0) \\
\hline 10 & $\begin{array}{l}\text { Scale with scattered cavities of the thickened ridges (1), no } \\
(0)\end{array}$ \\
\hline 11 & $\begin{array}{l}\text { Scale consist two or more longitudinal rows of circular } \\
\text { unpatterned areas (1), absent (0) }\end{array}$ \\
\hline 12 & $\begin{array}{l}\text { Scale consist a single row of large pits along the central } \\
\text { longitudinal axis (1), absent }(0)\end{array}$ \\
\hline 13 & Continuous submarginal ribs (1), absent (0) \\
\hline 14 & Submarginal parallel ribs on the anterior scale (1), absent (0) \\
\hline 15 & $\begin{array}{l}\text { Anterior submarginal rib with a wing-like structure (1), } \\
\text { absent }(0)\end{array}$ \\
\hline 16 & Distal edges of scales convex (1), no (0) \\
\hline 17 & Distal edges of scales concave (1), no (0) \\
\hline 18 & Small pores on the distal scale (1), absent (0) \\
\hline 19 & Densely spaced papillae on the distal scale (1), absent (0) \\
\hline 20 & $\begin{array}{l}\text { Two-lateral ribs and not connected on the scale (1), absent } \\
\text { (0) }\end{array}$ \\
\hline 21 & V-rib on the scale (1), absent (0) \\
\hline 22 & A flower like pattern in the angle of V-rib (1), no (0) \\
\hline 23 & Base of the V-rib broadly U-shaped (1), no (0) \\
\hline 24 & V-rib with large proximal hood (1), absent (0) \\
\hline 25 & Arms of V-rib bend (1), no (0) \\
\hline 26 & Arms of the V-rib completely encircle (1), no (0) \\
\hline 27 & A secondary layer on scale (1), absent $(0)$ \\
\hline
\end{tabular}


TABLE 2: Continued.

\begin{tabular}{ll}
\hline No. & Characters and status \\
\hline 28 & Body dome (1), absent (0) \\
29 & Dome of body scale very broad (1), no (0) \\
30 & Scale dome with parallel striation (1), absent (0) \\
31 & Dome with strongly U-shaped ribs (1), absent (0) \\
32 & A curved serrated bristle attached to dome (1), absent (0) \\
33 & Shield with labyrinthic ornamentation (1), absent (0) \\
34 & A row of minute holes on the shield (1), absent (0) \\
35 & A row of circular pits on the shield (1), absent (0) \\
36 & A dense reticulum of ribs on the shield (1), no (0) \\
37 & Regularly papillae on the shield (1), absent (0) \\
38 & A developed reticulum on distal 2/3 of the shield (1), absent \\
39 & Secondary structure on the shield and flange (1), absent (0) \\
40 & Small pores on the secondary layer of shield (1), absent (0) \\
41 & Large pores on the secondary layer of shield (1), absent (0) \\
42 & $\begin{array}{l}\text { A network of circular holes on secondary layer of shield (1), } \\
\text { absent (0) }\end{array}$ \\
43 & $\begin{array}{l}\text { An irregular reticulation of ribs on secondary layer of shield } \\
\text { (1), no (0) }\end{array}$ \\
44 & $\begin{array}{l}\text { Parallel transverse ribs on secondary layer of shield (1), } \\
\text { absent (0) }\end{array}$ \\
45 & Transverse rib connected run perpendicular (1), no (0) \\
46 & Cyst ovoid (1), no (0) \\
50 & Promst rhomboidal (1), no (0) \\
& Posterior flange ornamented (1), no (0) \\
&
\end{tabular}

To examine the relationship and the evolution of Mallomonas, two polygenetic trees of 39 species of Mallomonas recorded in China were gained from the hierarchical cluster analyses, which were conducted by SPSS 12.0, using Ward's method and furthest neighbor method, respectively. It was clear that the results of the two trees were largely consistent with each other (Figures 1 and 2). According to the two polygenetic trees, firstly, those 39 Mallomonas species could be divided into two major groups, with one cluster contains 31 species and the other one contains 8 species. Furthermore, to examine whether there were some characters that could be used to differentiate the upper cluster and the below cluster, all the 52 dual characters used were checked. And the shapes of the rip (V-rip or two lateral rip) and the submarginal rip were found to be the most two important characters to separate the two major clusters.

The upper cluster was composed of five groups: group I and group II together compose one subcluster, and the other three groups compose another one. Based on the result of Ward's method, group I included 6 species, M. annulata, M. calceolus, M. cratis, M. papillose, M. pseudocratis, and

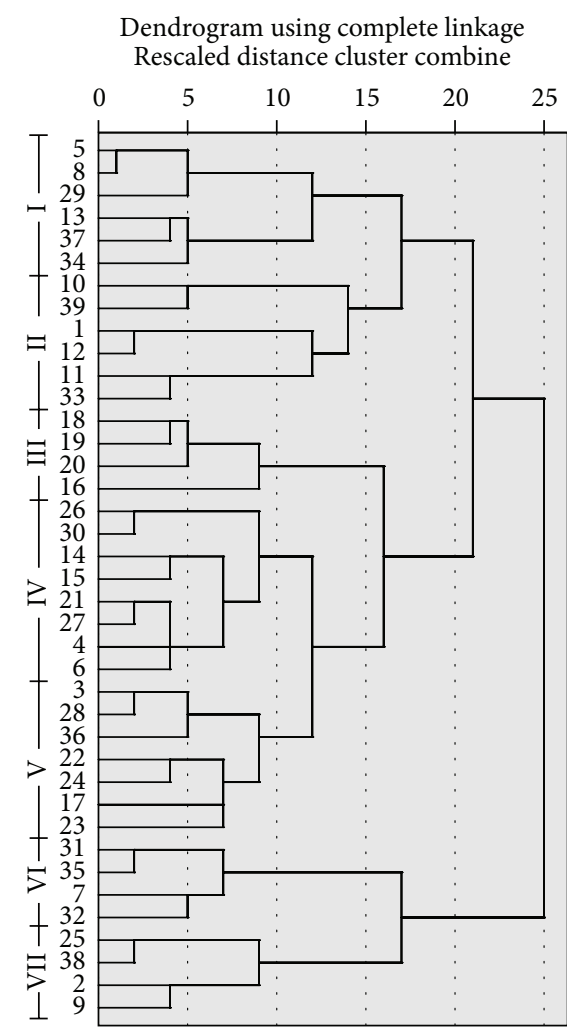

Figure 1: Dendrogram using furthest neighbor classification of 39 species of Mallomonas.

M. striata; group II included 6 species, M. acaroids, $M$. crassisquama, $M$. corymbosa, $M$. tonsurata, $M$. costata, and $M$. portae-ferreae. The characters of group I were that their scale had the dome, and the body of the scale presented ovoid shape. Furthermore, except M. annulata, the scales of the other 5 species were tripartite. Based on the taxonomic system set up by Kristiansen, M. calceolus and M. papillose belong to sect. Papillos, while M. cratis, M. pseudocratis, and M. striata belong to sect. Striatae. However, according to the result of the furthest neighbor method, M. costata and M. portae-ferreae also belonged to group I instead of group II. The characters of Group II were that their scales were arranged spirally and were typically tripartite, with densely arranged pores on the base plate. In addition, all of them had V-rib with acute angle. Moreover, the secondary layer of their shield may have ribs and reticulation structures. In the taxonomic system setup by Kristiansen [28], all of them belonged to sect. Mallomonas.

The other subcluster of the upper cluster was composed of groups III, IV, and V. Group III included 4 species and they were M. flora, M. guttata, M. guttata var. simple, and M. heterospina. The characters of this group are that the body scales of these species are spirally arranged, having longitudinal axes that are strongly oblique to the longitudinal axis of the cell. Secondly, their scales are present in an oval shape and the shields contain ribs. Thirdly, the cells are covered with curved bristles. In the taxonomic system setup by Kristiansen [28], M. flora belongs to sect. Striatae, M. guttata and M. guttata 


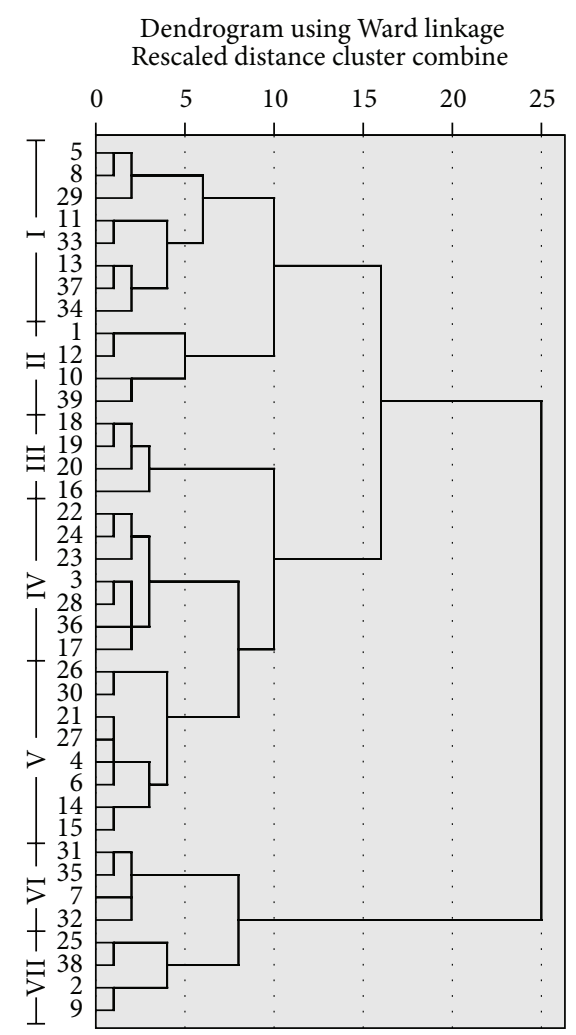

FIgURE 2: Dendroram using Ward's method classification of 39 species of Mallomonas.

var. simple belong to the species of sect. Papillose, and $M$. heterospina belongs to sect. Heterospinae, respectively. Group IV includes 8 species and they are $M$. alpine, $M$. areolata, $M$. elongate, M. multiunca, M. multisetigera, M. cyathelleta, $M$. insignis, and M. parvula. The characters of this group were that the scales are also spirally arranged. Moreover, their scales are thin, in oval or obovate shape, and contain V-ribs. The base plate of scales is closely spaced by pores. The dome concavity was shallow. The cells are covered with delicate bristles. In the taxonomic system of Kristiansen [28], M. alpine, $M$. areolata, M. elongate, and $M$. cyathelleta belong to sect. Mallomonas, while the others belong to different sections. Group V includes 7 species and they are $M$. alata, $M$. oviformis, $M$. rasilis, $M$. mangofera, $M$. splendens, $M$. grata, and $M$. eoa. The characters of this group are that the bristle of all the species of this group appeared at the apical end of the cell only and was smooth. The scales are rhombic. In the taxonomic system of Kristiansen [28], M. alata, M. grata, $M$. eoa, and M. mangofera belong to sect. Torquatae, and $M$. oviformis, M. rasilis, and M. splendens belong to sect. Planae, sect. Papillosae, and sect. Quadrata, respectively.

When we came to the following cluster, there were only two groups, groups VI and VII. Group VI contains four species, M. peronoides, M. peronoides var. bangladeshica, $M$. punctifera, and $M$. allorgei. These species had mixed characters, such as base plate with pores and scales with pits or papillae. In the taxonomic system of Kristiansen [28], $M$. peronoides and $M$. peronoides var. bangladeshica belong to sect. Planae. M. punctifera belonged to sect. Punctiferae, and $M$. allorgei belonged to sect. Quadrata.

The common traits of group VII are that the scales were arranged parallel to their longitudinal axes. Scales were without submarginal rib or V-rib. It included $M$. akrokomos, $M$. caudate, M. matvienkoae, and M. tolerans. However, based on Kristiansen's system [28], M. caudate, M. matvienkoae, and M. tolerans belonged to sect. Planae, while the M. akrokomos belonged to sect. Akrokomae.

\section{Discussion}

The taxonomy of the species was not fixed and would change with new methods involved. Numerical taxonomy, which could evaluate all of the characters simultaneously, is one of the popular methods used in the taxonomy of many species since it is more objective than the traditional ones. Mallomonas first was established as a genus in 1852. In total, 163 species have been reported, within which 39 species were recorded in China. The taxonomy of this genus had been modified for several times during the last 150 years; however, there were still divergences in the classification on the sections level. In our work, 39 species recorded in China were selected and analyzed by numerical taxonomy methods. When comparing the classification results of the further neighbor methods and Ward's methods, it could be found that they was almost the same to each other. This highly conformity implied that such classification was more appropriate. However, there was also a little difference between the two classification systems. In the classification of the further neighbor, M. costata and M. portae-ferreae belonged to group I (Figure 1); however, in the classification of Ward's method, they belonged to group II (Figure 2). In addition, when we turned to the traditional taxonomy of the two species, we found that both of them were classified in sect. Mallomonas. Therefore, the classification of Ward's method may be more reasonable than that of the further neighbor methods in Mallomonas.

When compared with the traditional taxonomy system, it could be concluded that the seven groups of the 39 Mallomonas reported in China divided by numerical taxonomy partly supported the traditional taxonomy setup by Kristiansen [28]. For example, all of the species of group II belonged to sect. Mallomonas. Similarly, in some other groups, most of the species belonged to one or two sections as described by Kristiansen's system. Three of six species in group I belonged to sect. Papillos and the other three belonged to sect. Striatae. In addition, four species out of eight in group IV belonged to sect. Mallomonas. Nevertheless, the classification suggested by numerical taxonomy showed a difference from the traditional classification. In the classification suggested by numerical taxonomy in our work, several species of one section in the Kristiansen's classification system belonged to different groups. Five species of sect. Papillos had been analyzed in the work and three of them belonged to group I and the other two belonged to group III. However, the two, which belonged to group III, were M. guttata and its variety, suggesting that this species was remote from the other species of this section. The same difference was seen in 
sect. Striatae, in which the M. flora was a little remote from the other species examined. Also, all of the ten species, which were divided into sect. Mallomonas, belonged to two different groups, with six of them in group II and the other four in group IV (Figures 1 and 2). Although all of the ten species shared a V-rip with acute angles, the scales of the six species of group II were thinner than that of the four of group IV, which meant that the classification of sect. Mallomonas was a little complicated and should be further examined. Taken together, our results of the classification suggested by numerical taxonomy not only partly supported the traditional classification, but also gave some new insights. It could be concluded that the classifications of most of Mallomonas species by different methods were matched in a certain degree, but some of them should be seriously considered and redivided by evaluating the numerical taxonomy results and the characters observed.

Several analyses using molecular and morphological data have been performed to begin to understand the phylogenetic relationships of Mallomonas. Lavau et al. [30] found Mallomonas species that formed a monophyletic clade among 10 Mallomonas species, 6 Synura species, and 1 Tessellaria species based on nuclear SSU rDNA data and scale characteristics. Andersen [31] has performed molecular phylogenetic analysis of the synurophyceae and chrysophyceae using nuclear SSU rDNA and $r b c \mathrm{~L}$ gene. Based on his work, the genus Mallomonas was polyphyletic in the $r b c \mathrm{~L}$ phylogenetic tree but was not resolved based on nuclear SSU rDNA sequence data. It had determined the sequences for both the nuclear SSU and LSU rDNA and plastid LSU of RUBISCO $(r b c \mathrm{~L})$ genes of 19 Mallomonas isolates. Bayesian and maximum-likelihood (ML) analyses of the data revealed that Mallomonas consists of two strongly supported clades. The results indicated that the sections Planae and Heterospinae should be combined. The findings also clearly indicated that at least some features of the current infrageneric classification of Mallomonas based on scale ultrastructure are not congruent with our molecular phylogeny [28]. It is not so surprising since the relationships between the sections and series lack phylogenetic underpinnings and have been considered as artificial by Kristiansen and Preisig [32]. It is suggested that the current classification of the genus Mallomonas at the section level would require some revision [33].

The tools of geometric morphometrics are currently considered the most powerful in biological shape analysis [3437] and are now widely used in almost all branches of organismal biology [38]. So far in phycology, the landmark-based geometric morphometric methods were used in taxonomic investigations of diatoms [39], macroscopic green algae [40, 41], and the variation in scales of M. striata [42]. A wide field for geometric morphometric analyses in the investigation of both synurophycean taxonomy and ecology, especially in species with rich and complex morphology of scales bearing structures, allows the delimitation of landmarks (most Synura species, members of the sections Papillosae, Heterospinae, Striatae, and Pseudocoronatae of the genus Mallomonas, and others) [42].

Although the results acquired by the numerical taxonomy are more objective and explicit, it could not absolutely take the place of the traditional taxonomy. In addition, geometric morphometric studies and molecular information are becoming powerful evidence in taxonology of the algae. Therefore, the numerical taxonomy associated with the morphometric features, geometric morphometry, and sequence analysis would define much clearer groups of Mallomonas in advance.

\section{Acknowledgment}

This study was financially supported by the National Natural Science Foundation of China (Grant no. 30770162).

\section{References}

[1] M. Perty, Zur Kenntnis kleinster Lebensformen nach Bau, Funktionen, Systemtik mit Spezialverzeichniss der in der Schweiz beobachteten, Bern, Switzerland, 1852.

[2] R. A. Andersen, "Synurophyceae Classis nov., A new class of algae," American Journal of Botany, vol. 74, pp. 337-353, 1987.

[3] B. V. Skvortzov, "Harbin Chrysophyta, Chinae Boreali-Orientalis," Bullutin Herbin North-Eastern Forestry Academy, vol. 3, pp. 1-70, 1961.

[4] L. S. Péterfi and B. Asmund, "Mallomonas portae-ferreae nova species in the light and electron microscopes," Studia Universitatis Babes-Bolyai, vol. 1, pp. 11-18, 1972.

[5] B. Asmund and J. Kristiansen, "The genus Mallomonas (Chrysophyceae)," Opera Botanica, vol. 85, pp. 1-129, 1986.

[6] J. Kristiansen and D. Tong, "Silica-scaled Chrysophytes of Wuhan, a preliminary note," Journal of Wuhan Botanical Research, vol. 6, pp. 97-100, 1988.

[7] J. Kristiansen, "Silica-scaled chrysophytes from China," Nordic Journal of Botany, vol. 8, pp. 539-552, 1989.

[8] J. Kristiansen and D. Tong, "Chrysosphaerella annulata n. sp., a new scale-bearing Chrysophyte," Nordic Journal of Botany, vol. 9, pp. 329-332, 1989.

[9] J. Kristiansen and D. Tong, "Studies on silica-scaled Chrysophytes from Wuhan, Hangzhou, and Beijing, P. R. China," Nova Hedwigia, vol. 49, pp. 183-202, 1989.

[10] J. Kristiansen, "Studie on silica-scaled Chrysophytes from Central Asia, from Xinjiang and from Gansu, Oinghai, and Shaanxi Provinces, P. R. China," Archiv für Protistenk, vol. 138, pp. 298303, 1990.

[11] J. Kristiansen and D. Tong, "Investigations on silica-scaled Chrysophytes in China," Verhandlungen der Internationalen Vereinigung für Theoretische und Angewandte Limnologie, vol. 24, no. 4, pp. 2630-2633, 1991.

[12] W. Y. X. Wei Yin Xin and J. Kristiansen, "Occurrence and distribution of silica-scaled chrysophytes in Zhejiang, Jiangsu, Hubei, Yunnan and Shandong provinces, China," Archiv für Protistenkunde, vol. 144, no. 4, pp. 433-449, 1994.

[13] W. Yin-xin and J. Kristiansen, "Studies on silica-scaled chrysophytes from Fujian Province, China," Chinese Journal of Oceanology and Limnology, vol. 16, no. 3, pp. 256-266, 1998.

[14] Y. X. Wei and X. P. Yuan, "Studies on silica-scaled Chrysophytes from the tropics and subtropics of China," Beihefte zur Nova Hedwigia, vol. 122, pp. 169-187, 2001.

[15] R. M. M. Roijackers and H. Kessels, "Ecological characteristics of scale-bearing Chrysophyceae from the Netherlands," Nordic Journal of Botany, vol. 6, pp. 373-383, 1986. 
[16] P. A. Siver, The Biology of Mallomonas, Kluwer Academic Publishers, Dordrecht, The Netherlands, 1991.

[17] P. A. Siver, "Inferring the specific conductivity of lake water with scaled chrysophytes," Limnology and Oceanography, vol. 38, no. 7, pp. 1480-1492, 1993.

[18] P. A. Siver and A. M. Lott, "Preliminary investigations on the distribution of scaled chrysophytes in Vermont and New Hampshire (USA) lakes and their utility to infer lake water chemistry," Nordic Journal of Botany, vol. 20, no. 2, pp. 233-246, 2000.

[19] J. P. Smol, "Application of chrysophytes to problems in paleoecology," in Chrysophyte Algae. Ecology, Phylogeny and Development, C. D. Sandgren, J. P. Smol, and J. Kristiansen, Eds., pp. 303-330, Cambridge University Press, Cambridge, UK, 1995.

[20] L. Lwanoff, "Beitrag zur Kenntniss der Morphologie und Systematik der Chrysomonaden," Bulletin de l'Académie Impériale des Sciences de Saint Pétersbourg, vol. 11, pp. 247-262, 1899.

[21] W. Conrad, "Le genre Microglena Ehrenberg C G," Archiv Für Protistenk, vol. 60, pp. 415-439, 1927.

[22] W. Conrad, "Revision du genre Mallomonas Perty et Pseudomallomas Chodat," Mémoirs du Museum d'histoire Naturelle Belgique, vol. 56, pp. 1-82, 1933.

[23] P. Bourrelly, "Recherches sur les Chrysophycees, morphologie, phylogenie, systematique," Revue Algologique Mémoire Serie, vol. 1, pp. 337-368, 1957.

[24] K. Harris and D. E. Bradley, "An examination of the scales and bristles of Mallomonas in the electron microscope using carbon replicas," Journal of the Royal Microscopical Society, vol. 76, no. 1-2, pp. 37-46, 1957.

[25] K. Harris and D. E. Bradley, "A taxonomic study of Mallomonas," Journal of General Microbiology, vol. 22, pp. 750-777, 1960.

[26] L. S. Péterfi and L. Momeu, "Romanian Mallomonas species studied in light and electron microscopes," Nova Hedwigia, vol. 27, pp. 353-392, 1976.

[27] L. Momeu and L. S. Péterfi, "Taxonomy of Mallomonas based on the fine structure of scales and bristles," Contributions to Botany Cluj-Napoca, vol. 19, pp. 13-20, 1979.

[28] J. Kristiansen, "The genus Mallomonas (Synurophyceae)-a taxonomic survey based on the ultrastructure of silica scales and bristles," Opera Botanica, vol. 139, pp. 5-218, 2002.

[29] W. D. Lu, SPSS for Windows, Publishing House of Electronics Industry, Beijing, China, 2003.

[30] S. Lavau, G. W. Sounders, and R. Wetherbee, "A phylogenetic analysis of the synurophyceae using molecular data and scale case morphology," Journal of Phycology, vol. 33, no. 1, pp. 135151, 1997.

[31] R. A. Andersen, "Molecular systematic of the Chrysophyceae and Synurophyceae," in Unravelling the Algae: The Past, Present, and Future of Algal Systematics, J. Brodie and J. Lewis, Eds., pp. 285-313, CRC Press, Boca Raton, Fla, USA, 2007.

[32] J. Kristiansen and H. R. Preisig, "Süßwasserflora von Mitteleuropa Freshwater Flora of Central Europe," in Chrysophyte and Haptophyte Algae, vol. 2 of Teil/Part2: Synurophyceae, Springer, Berlin, Germany, 2007.

[33] B. Y. Jo, W. Shin, S. M. Boo, H. S. Kim, and P. A. Siver, "Studies on ultrastructure and three-gene phylogeny of the genus Mallomonas (synurophyceae)," Journal of Phycology, vol. 47, no. 2, pp. 415-425, 2011.

[34] F. L. Bookstein, Morphometric Tools for Landmark Data: Geometry and Biology, Cambridge University Press, Cambridge, UK, 1991.
[35] I. L. Dryden and K. V. Mardia, Statistical Shape Analysis, John Wiley \& Sons, New York, NY, USA, 1998.

[36] F. J. Rohlf, "Statistical power comparisons among alternative morphometric methods," American Journal of Physical Anthropology, vol. 111, pp. 463-478, 2000.

[37] M. L. Zelditch, D. L. Swiderski, D. H. Sheets, and W. L. Fink, Geometric Morphometrics for Biologists: A Primer, Elsevier Academic Press, London, UK, 2004.

[38] D. C. Adams, F. J. Rohlf, and D. E. Slice, "Geometric morphometrics: ten years of progress following the 'revolution"' Italian Journal of Zoology, vol. 71, no. 1, pp. 5-16, 2004.

[39] B. Beszteri, É. Ács, and L. Medlin, "Conventional and geometric morphometric studies of valve ultrastructural variation in two closely related Cyclotella species (Bacillariophyta)," European Journal of Phycology, vol. 40, no. 1, pp. 89-103, 2005.

[40] H. Verbruggen, O. De Clerck, E. Cocquyt, W. H. C. F. Kooistra, and E. Coppejans, "Morphometric taxonomy of siphonous green algae: a methodological study within the genus Halimeda (Bryopsidales)," Journal of Phycology, vol. 41, no. 1, pp. 126-139, 2005.

[41] H. Verbruggen, O. De Clerck, W. H. C. F. Kooistra, and E. Coppejans, "Molecular and morphometric data pinpoint species boundaries in Halimeda section Rhipsalis (Bryopsidales, Chlorophyta)," Journal of Phycology, vol. 41, no. 3, pp. 606-621, 2005.

[42] J. Neustupa and Y. Němcová, "A geometric morphometric study of the variation in scales of Mallomonas striata (Synurophyceae, Heterokontophyta)," Phycologia, vol. 46, no. 2, pp. 123-130, 2007. 

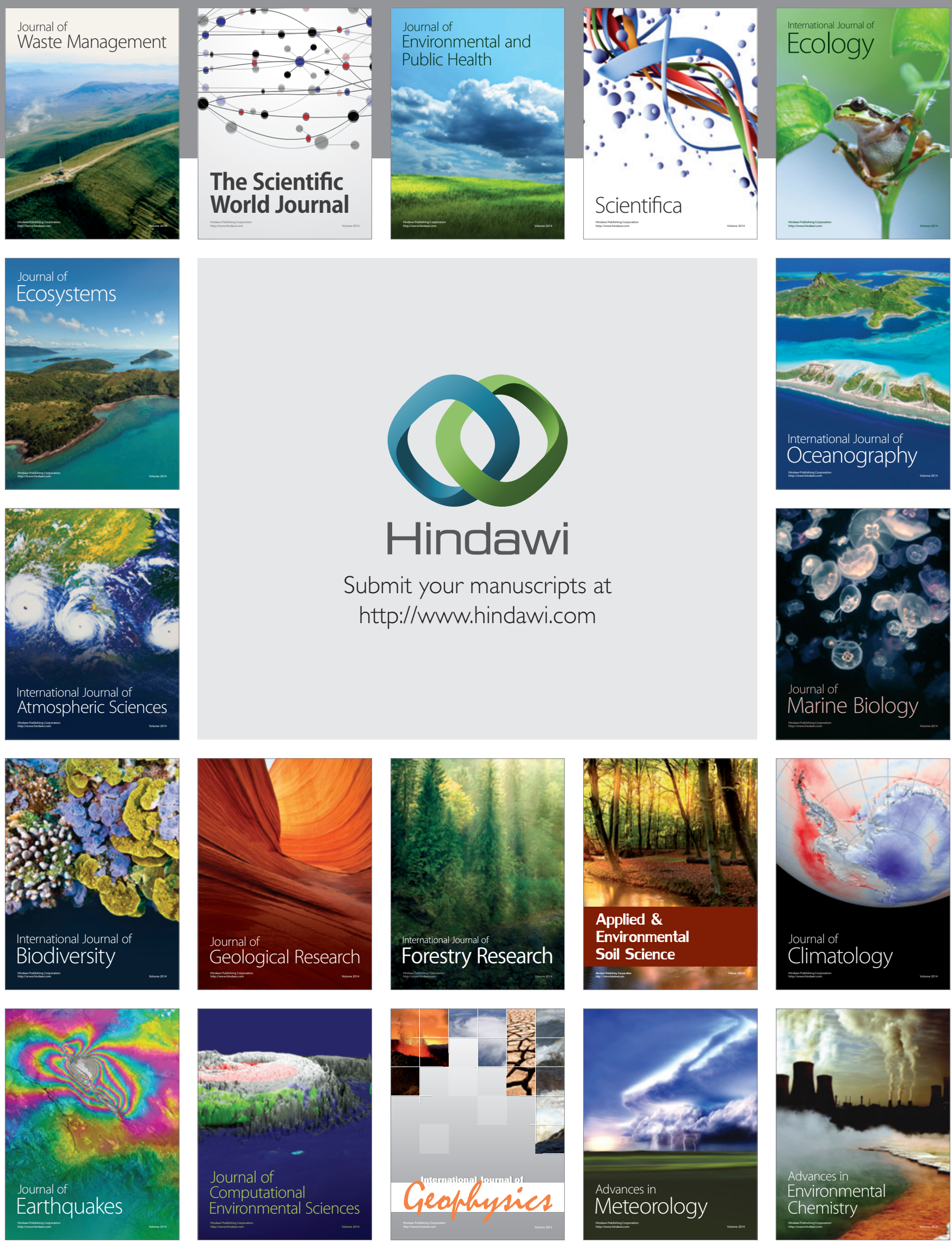